\title{
On Some Functional-Stylistic Peculiarities of the Language of Religion
}

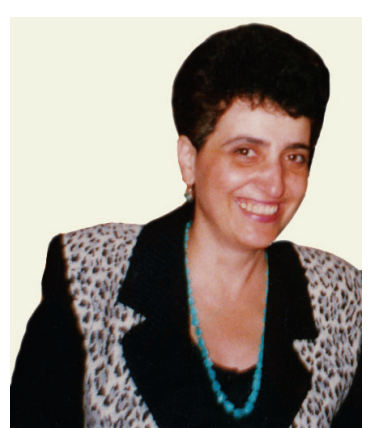

Naira Gasparyan

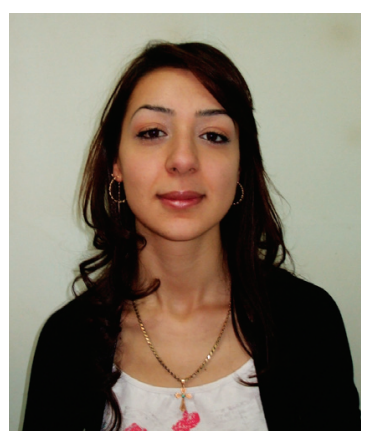

Arevik Ajamoghlyan

The specific area of religious communication through

the Holy Books is a very prolific field of linguistic research, yet, it has not been focused on as a discourse variety in the system of functional styles. ${ }^{1}$ The aim of the present paper is to show that the language of religion, one of the stylistic varieties of standard English language, is a specific field of linguistic study, with a big set of style-forming features typical of the language of religion in general and of that of the Holy Books in particular. To prove this statement we have carried out a research based on the English texts of the Bible and the Quran. An effort has been made to show that despite differences of cultural backgrounds, mentality, psychology, individual and social behaviours reflected in the Bible and in the Quran, both of the Holy Books contain similar images, ways of expression, several unique modes of combining language units into a linguistic pattern. The similarities may be explained by a common origin or source and by a number of human factors, i.e. the histories of the Bible and the Quran are closely connected with the history of various ethnicities and their evolution.

Today's public interest in the Holy Books has made the language of religion an attractive object of linguistic study. What we are interested in is not the social, cultural or religious background (extralinguistic factors) of the Holy Books, but the linguistic expression and similarities that are based on the above mentioned factors.

All functional varieties of the literary English language are invariant systems, due to stylistic differentiation on the level of sub-style and genre. Functional styles are distinguished on the basis of the variety of two main functions (aesthetic and intellective), respectively sub-styles and genres of the given style are its minor expressions. What brings them together is the function of the "parent" style which is common for all the discourse types of the given style. The certain sphere of communicative activity, based on a number of extralinguistic factors, conditions the selection of special linguistic means and forms of expression. Each functional variety or register (as the English linguists name a discourse type) may be characterized by a number of distinctive features, leading or subordinate, constant or changing, obligatory or optional. The language of religion, according to the modern approach, is viewed either 
as a separate functional style (Naer 1988)2 or as a generic variety within the Functional Style of Worship, expressed in two genres, those of church and religion. The author of the latter classification, N.A. Baskakov, makes an attempt to establish the place of the language of religion through the specific set of linguistic peculiarities demonstrated in the style (Baskakov 1983).

The most interesting and reasonable one of the existing theories seems to be the one presented by V.L. Naer. The author himself states that he does not want to oppose to the traditionally existing theories, but it is time to face the objectively existing reality to define the language of religion as a separate style. V.L. Naer mentions that the Style of Religion possesses all the characteristics of a distinctive functional style and, hence it can be defined as a special variety of the literary language having a specific aim in communication - expression or appearance of religious consciousness through intensive emotional interaction based on a definite system of specific linguistic means. In his functional classification system the language of religion (as a separate functional variety of speech) has its own sub-styles: the language of the Bible, the language of prayers and the language of religious sermons (Naer 1988).

Every society needs some laws to prevent injustice and preserve the rights of every member of the society. Be he an aristocrat or a democrat, a monarch or a dictator, first of all, he will instinctively look after his own interest. Everyone is capable of wrong judgment; and a lot of wrong decisions do not add up to a right decision. No man or a group of men is in position to make a comprehensive law based on perfect equity and justice. So it is necessary that the law should be made by someone who is superior to man, who has nothing to lose or gain by that law and with whom every man has equal relation. Here arises the need of religion and religious principles which could be spread through written texts. The created religious books are meant for masses, for ordinary people, educated or uneducated, poor or rich in contrast to scientific writing which is meant for certain groups of educated people. The Holy Bible, as well as the Quran, is a kind of a tool with the help of which human attention, and thoughts are focused on God's/Allah's instructions, human activity is directed to self-improvement, kindness, dedication and peaceful coexistence. Their subject matter touches upon man's very existence, his origin, purpose and destination. For countless generations men have been instructed to seek reason for their lives on the pages of The Holy Bible and the Quran. Men have sought comfort, strength, consolation or inspiration and have found these blessings to bring them emotional comfort.

In fictive writing the communication aim, the aesthetic impact on the reader, is secured by emotive-evaluative overtones, but the Holy Book is not simply read to enjoy its language or to enjoy the Ten Commandments. God's instructions are not enjoyed! They must be learned, and people should obey these instructions if they want to lead a decent life! Since the Bible is meant for masses, Bible images should appeal both to the readers' emotions and mind and this means that they must be expressive and impressive, yet, simple and easy to perceive. The images are closely linked to reality, to the lives of those who read the Holy Books and learn the philosophy of life. The Holy Books aim at teaching people and expanding progressive ideas. 
Thus, the Bible and the Quran can be viewed as eternal oceans of knowledge and most powerful means in the process of cognition. For example, the person, according to the Holy Bible, is like a desert. As the desert is thirsty of water, so is the person thirsty of God (Ghushchyan 2006:66-70). These and other such images have a great impact on the readers' and listeners' mind and will. Tropes and various figures of speech help to create a unique atmosphere which realize not only the function of emotive impact but also the cognitive one. ${ }^{3}$ Readings of the Holy Books first of all enrich people's "scientific knowledge" and widen their intellectual horizon. They are not meant to enslave people or spread fear. There are lines in the Quran that state this. Does it not mean that the language used in this domain realizes very specific and unique intellective communication? There are many opinions on the matter but it still requires much attention and consideration since images and the variety of symbols in both of the Holy Books bear great significance in understanding human nature, mission and purposes.

The Muslim culture informs us that Allah is Omnipotent and Merciful, he is Power himself, Virtue himself, Mercy himself. The Quran rejects Father-Son relationship and Trinity in general, and according to it, the sacred relationship is between Allah and his servant. From any small piece of informative religious discussion it becomes clear that the Holy Books present written pieces containing a great number of special terms called religious vocabulary.

Wikipedia, the free encyclopedia, defines religious terminology as specialized terms used within the context of a particular religion as a largely self-contained language system. Particular terms may express concepts which may be unique to that religion, or may otherwise be translatable to concepts present in other religious systems, as well as to secular terms. Most terms are distinguished by cultural differences. The term Christianese is an exonym from secular culture to refer to the language of terms used in the language of Christianity and, in some cases, deliberately or effectively uncooperative with secular and foreign terms. In the developed Christian context, particular terms (Christianese) like God and Christ (or Jesus) as well as more common terms such as faith, truth, and spirit have a rich history of meaning to refer to concepts in spirituality, which Christians may consider to be particular to Christianity, and not available to dissimilar or distantly foreign belief systems.

It is common knowledge that the use of terms is not a specific feature of fiction writing, but the religious type of text cannot be regarded as scientific writing either since it does not contain any general scientific vocabulary. Anyhow, the religious variety of speech does not only instruct and teach. Aesthetic-emotive-evaluative overtones in the language of religion help to bring consolation and comfort to the heart of the reader after the latter has obtained the necessary knowledge. Moreover, there is no other book in the world that during one's whole lifetime is referred to as often as it is done in this case. With every reading the message is interpreted in a new light, depending on the new circumstances and experiences in the reader's life. There is no other book in the world that can arouse so much emotion and transmit so much wisdom. But no matter how expressive the religious images and symbols, they do not secure the aesthetic impact that fiction provides. It is the impact of philosophy that profoundly penetrates into the 
reader's consciousness, mind and soul, refreshing the knowledge, purifying the thought, making him/her wiser, kind and strong, more merciful. And what is more important, there is no other variety of language which has taken the responsibility to rescue the sinful, to make a criminal an obedient and model citizen. This is the magic of the Holy Books.

As already mentioned above, the language of religion has no fixed place in the traditional functional-stylistic system of speech. It can only be argued whether it is a variety of fiction, official or scientific language or the language of everyday communication. The characteristic features of this unique sphere of communication make the discourse easily recognizable due to its symbols, carefully wrought miraculous images and the verbal expression of universal wisdom. It is beyond doubt that a piece of prayer or religious text can never be mixed up with other types of texts. In our opinion religious symbols and images can even be regarded as stylistic markers for the register, markers which possesses a highly cognitive value secured by impact and persuasion. They also inform, realize a specific type of communication between people and God/Allah. So, the language of church and religion besides the emotive function, realizes cognitive, referential (informative) and communicative functions of speech as well. The language of religion can be defined as an emotive-evaluative language of instruction.

As the investigation shows the Quran displays very similar linguistic peculiarities when compared with the Bible; numbers, images, symbols, the same ideas expressed through the same tropes and figures of speech. Both books teach and instruct through a number of common morpho-syntactic means.

Imperative mood, the axis of order, is abundantly found in the language of religion, thus becoming an important style forming peculiarity, as for instance:

$$
\begin{aligned}
& \text { Wash you, make you clean; put away the evil of your doings from } \\
& \text { before mine eyes; cease to do evil. } \\
& \text { (Holy Bible, Old Testament; the Book of the Prophet Isaiah, } \\
& \text { Chapter I., p.291) } \\
& \text { Don't tell anyone about this vision you have seen until the Son of Man } \\
& \text { has been raised from death. } \\
& \text { Warn your nearest relations. }
\end{aligned}
$$

Each image has a spiritual meaning and conveys a certain instruction or a piece of advice. Symbols and images used in the Bible transmit God's instructions to people. Often the same symbols are observed in the text of the Quran. Number twelve is very particular both in the Bible and in the Quran. Jesus Christ selects twelve apostles and the Ithna Asharis believes in twelve imams. "Ithna Ashariyyah" itself means belonging to twelve.

The symbol of water is an essential element both in the Bible and in the Quran. Water is the symbol of life as Christ was baptized in the river, and, generally, where 
Christ appears there appears water. Bread is also regarded as symbol of life in the Bible. It is seen in the prayer. While praying, people ask God for everyday bread to live on.

God our in the heaven...

give us our everyday bread...

(New Testament for Children; $p$. 335)

Blood symbolizes salvation as after the resurrection of Christ he comes and tells his followers that the wine they drink is his blood. When Jesus was crucified there was blood on his wounded body.

A symbolic interpretation is an optional extension of meaning. The potential for a symbolic interpretation is triggered by an apparent violation of one or more of the maxims - particularly those of quantity, manner or relation. A symbolic passage is always interpretable on a literal level; it is up to the reader, on the basis of experience of the text, the genre, and encyclopedic knowledge, to go further. It is the result of interpretation between text and reader; it is optional interpretative strategy which the reader may choose to adopt. ${ }^{4}$

Images and symbols in the Bible and in the Quran are never abstract, they always present something and denote something that can be seen and touched upon. They are always motivated: they either teach or instruct, they help to live and succeed. They have inner spiritual sense, character of expression. Symbolic associations are out of control, symbolic meanings are natural and unavoidable. Although symbols often have universal meaning, different symbols may have quite different meanings in different cultures. That is why part of the symbols in the Bible and in the Quran are associated with the same objects and concepts, while others are connected with different ones.

For example, when God decided to create the light after creating the World, he created the Sun, then to distinguish darkness from light, he created the Moon and the Stars. The lines appear in the form of a sequence, the first point of which accounts for the next part.

In the beginning God created the heaven and the earth And God said, Let there be light: and there was Light: and God divided Light from the darkness".

(The First Book of Moses, Genesis; Chapter I)

The views of water, firmaments, land, vegetations are also described in that way. The Holy Book gives the description of manhood, i.e. how God created Man and Woman.

And the Lord God planted a garden and put there the man whom he had formed.

...And the Lord God said, It is not good that the man should be alone;

I will make a meet for him. 


\section{...And the rib which the Lord God had taken from the man, made he woman, and brought her unto the man.}

(The First Book of Moses, Genesis; Chapter II)

In the text of The Bible the tree symbolizes two things: liveliness and wisdom. As when Eve ate the fruit from the tree and gave her husband Adam to eat, suddenly they realized that they were naked and felt ashamed. Then they made aprons to close the parts of their bodies. Adam and Eve ate the fruit from the tree and got blind and deaf as they did not follow God's instructions when he ordered not to eat from that tree. God's instructions should never be doubted. Those who obey always gain. Losses are also for people. When you lose you should do it reservedly, because life is a ladder, some lose others gain and vice versa. People should always be content with what God sends them.

The ear and the eye in the Bible are presented not by their direct definition, but by their spiritual meaning. So, in the Holy Bible, to have eyes and ears means to hear and obey.

And when the woman saw that the tree was good for food, and that it was pleasant to the eyes, and a tree to be desired to make one wise, she took of the fruit, and did eat, and gave also unto her husband with her; and he did eat.

(Holy Bible 1993, Old Testament)

The personality of Adam, the first Prophet, is found in the Quran, as well. Here he is designated to fulfil the role of Allah's deputy and khalifah on the earth. The investigation of both of the texts reveals that the same language is used in both cases irrespective of the fact whether the images are the same or different. Direct order and instructions with imperative mood, or indirect order with the verb let, rhetoric questions, colourful images and symbols with profound philosophy and high emotionality serve to realize certain linguistic functions. There are a number of psalms where metaphor is used to create images of priests (...sitting on the chair like an emerald), who are God's servants and their duty is to spread his message among those who need it like water and air.

As it is known, a greater or lesser volume of emotiveness is distinguished in interjections and exclamatory words which have emotive meaning in their semantic structure and that is why are the most highly emotively charged words. ${ }^{5}$ As expressions of deep human feelings, interjections are abundantly used in the Bible.

Tell me, O thou whom my soul loveth, where thou feedest, where thoumakest thy flock to rest at noon:

for why should I be as one that turneth aside by the flocks of thy companions.

(Holy Bible; Book of the Old Testament, The Song of Solomon, Chapter I, p. 290) 
Oh, why I am so sad?

Oh, that's a good idea!

O, People of the House.'

(Quran, p. 331)

Oh itself may express various feelings: regret, disappointment, sorrow, surprise, astonishment and others.

Oh! Ah! Pooh! Gosh! Hush! Alas! are primary interjections free from any logical meaning; Heavens! Dear me! God! Come on! Look here! God knows and others are considered to be named as exclamatory words and word-combinations used as interjections and contain some quantity of logical meaning. It is obvious that interjections bear direct signals that the utterance is emotionally charged.

\section{Ye serpents, ye generation of rippers,}

How can ye escape the damnation of hell?

(Holy Bible 1993, New Testament; St. Matthew,

Chapter XXIII, p. 14)

In The Bible inner represented speech is used to give persons and their relationships a new and specific meaning. It also makes the utterance easier to understand. In this way some special and friendly atmosphere is created between the addresser and the addressee. People are more apt to learn what is said in a rather friendly tone, and people are willing to follow God's advice and instructions. The use of inner represented speech helps the reader to come closer to God.

Miracles witness that Christian God and Muslin Allah are Almighty and Omnipotent. The prophets were given miracles as their credentials. Miracles, according to our belief, are such performances which are not impossible, but which cannot be done without apparatus, medicine or practice. But the prophet performs them without any practice and machinery. Jesus Christ's miracle was that he cured the blind persons and lepers without any medicine. The Muslims consider the Quran to be the greatest living miracle, the one of Muhammad's innumerable miracles.

When prophet Muhammad went to heaven in his lifetime and narrated the happenings after his return, his enemies said, "How was it possible to go to heaven with body?" But believers know if an infallible Prophet says that he did go to heaven, it was not impossible. Now the recent advent of science has proved it right. Where scientists are trying to go by spaceship 6 Muhammad went without any aid or machine and that was his miracle (Quran 1934).

As a conclusion it should be stated that the style of religion together with its generic expressions should be defined as a separate and unique functional variety or discourse type in the system of functional styles as it obviously has a definite communicative aim to realize, is based on certain norms of expression and a specific system of interrelated linguistic and stylistic means. 


\section{Notes:}

1. The review of linguistic literature reveals that there exist various approaches towards the classification of functional styles: traditional, based on the three basic functions of speech which lead to the realization of a certain aim in communication (Vinogradov V.V., Razinkina N.M., Galperin I.R ) and modern, when other factors become significant (Naer V.L., Baskakov N.A.).

2. V.L. Naer distinguishes between three types of communication: Professional Business Communication, Mass Communication and Belles-Letters' Communication which realizes an aesthetic function. The mentioned three global styles of communication are called megastyles, and are opposed to macrostyles and microstyles (sub-styles, genres). The functions of speech, according to him, are not the most important criteria in functional stylistic classification (Naer 1981,1988).

3. All forms of language are innately symbolic, and any system of symbols can form a 'language'; at the minimum using only two arbitrary symbols in a binary system. Human oral language is based on use of phonemes as representative symbols, and the analogous written forms are typically differential to the phoneme. The written word is therefore symbolically representative of both the symbolic phoneme and directly to the cognitive concept which it represents. The field of cognitive linguistics explores the cognitive process and relationships between different systems of phonetic symbols to indicate deeper processes of symbolic cognition. Many cultures have developed complex symbolic systems, often referred to as a symbolic system which assigns certain attributes to specific things, such as types of animals, plants or weather.

4. As there exist different versions of The Bible and the Quran, facts can be a bit differently interpreted and discussed in those versions (Mkrtichian 1998:111-116).

5. In traditional grammars interjections are considered to be a part of speech. But there is another view according to which interjections are considered to be not a part of speech but a sentence. The pauses between words are very brief while the pause between the interjection and a word is so long that it can be understood as pauses between sentences. The pauses between interjections can be supposed as a transfer from the emotional to the logical or vice versa.Interjections in the English vocabulary are marked as bookish, neutral, or colloquial. For instance $O h$, ah are neutral, alas is bookish, gosh is colloquial (Galperin 1977).

6. The speech variety which contains terms to talk about miracles and the inexplicable, is called Science Fiction. Functions of speech dominating in this type of writing are the cognitive, communicative and intellective ones, realized along with that of the aesthetic impact. 


\section{References:}

1. Baskakov, N.A. (1983) Strukturniye i funktsionalniye stilisticheskie modifikatsii v sovremennikh tyurkskikh yazikakh. Moskva.

2. Galperin, I.R (1997) Stylistics. Moscow: Visshaya Shkola.

3. Ghushchyan, G. (2006) Saghmosneri dardzvatsabanutyuny // Astghik. Yerevan: Sahak Partev, N 16.

4. Langacker, R.W. (1991) Concept, Image and Symbol. New York.

5. Mkrtichian, S. Bible Translation (1998) // Astghik. Yerevan: Sahak Partev, N 8.

6. Naer, V.L. (1981) K opisaniyu funktsionalno-stilevoy sistemi sovremennogo angliyskogo yazika: Voprosi diferentsiatsii $i$ integratsii. // Lingvisticheskiye osobennosti nauchnogo teksta. Moskva: Nauka.

7. Naer, V.L. (1988) O tekstovikh parametrakh funktsionalnogo stilya. K postanovke problemi. Tekst v funktsionalno-stilisticheskom aspekte. Moskva: Nauka.

8. Nazarenko, A.L. (2000) Nauchno-populyarnaya literatura kak obyekt funktsionalnoy stilistiki i lingvodidaktiki. Avtoreferat diss. ... dokt. filolog. nauk. Moskva.

9. Razinkina, N.M. (1972) Stilistika angliyskoy nauchnoy rechi. Elementi emotsionalno-subyektivnoy otsenki. Moskva: Nauka.

10. (1993) The Holy Bible. King James Version. Ashland, Ohio, USA, Landoll.

11. Vinogradov, V.V. (1981) Problemi russkoy stilistiki. Moskva: Nauka.

12. Vinogradov, V.V. (1955) O ponyatii stilya yazika.// Izv. AN USSR. Moskva. Vol.14. Vip. 4.

13. Yusuf, Ali, A. (1934) Quran.

14. W.O.F.I.S. Islam. http://www.wofis.com

\section{unnah Ltiquh nnn2 qnnómnulyma-nбulyma unuGăGưhuunlnıpjnıGGitph 2nเn2}

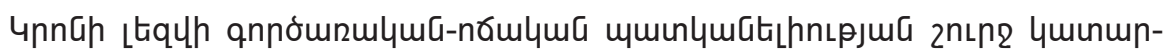

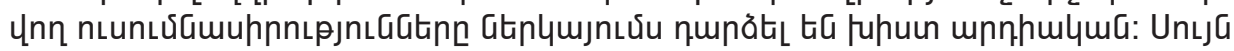

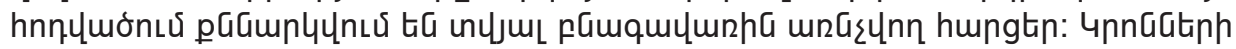

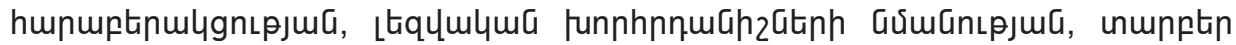

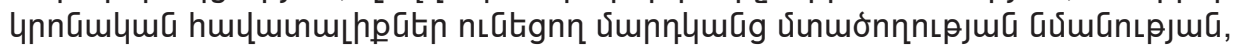

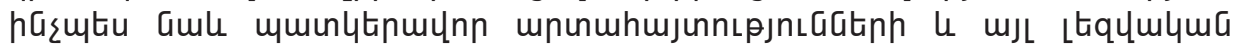

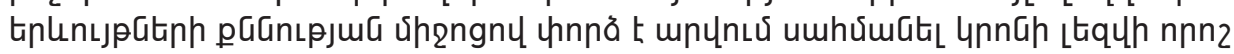

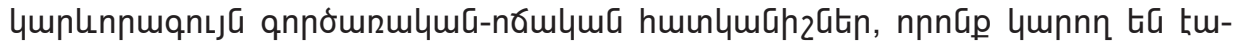

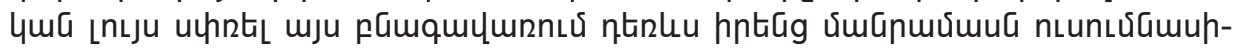
nnıpjnıĞ ¿uunuguơ tinlinsjpGitph unu: 